University of Nebraska - Lincoln

DigitalCommons@University of Nebraska - Lincoln

\title{
Cleat-Filling Calcite in Illinois Basin Coals: Trace-Element Evidence for Meteoric Fluid Migration in a Coal Basin
}

\author{
Allan Kolker \\ University of Nebraska-Lincoln \\ Chen-Lin Chou \\ Brookhaven National Laboratory
}

Follow this and additional works at: https://digitalcommons.unl.edu/geosciencefacpub

Part of the Earth Sciences Commons

Kolker, Allan and Chou, Chen-Lin, "Cleat-Filling Calcite in Illinois Basin Coals: Trace-Element Evidence for Meteoric Fluid Migration in a Coal Basin" (1994). Papers in the Earth and Atmospheric Sciences. 330. https://digitalcommons.unl.edu/geosciencefacpub/330

This Article is brought to you for free and open access by the Earth and Atmospheric Sciences, Department of at DigitalCommons@University of Nebraska - Lincoln. It has been accepted for inclusion in Papers in the Earth and Atmospheric Sciences by an authorized administrator of DigitalCommons@University of Nebraska - Lincoln. 


\title{
GEOLOGICAL NOTES
}

\section{Cleat-Filling Calcite in Illinois Basin Coals: Trace-Element Evidence for Meteoric Fluid Migration in a Coal Basin ${ }^{1}$}

\author{
Allan Kolker ${ }^{2}$ and Chen-Lin Chou ${ }^{3}$ \\ Department of Applied Science-Bldg. 815, Brookhaven National Laboratory, Upton, NY 11973
}

\begin{abstract}
A B S TRACT
The microdistribution of $\mathrm{Mn}$ (786 to $9480 \mathrm{ppm}$ ), $\mathrm{Sr}$ (<5 to $461 \mathrm{ppm}$ ), and $\mathrm{Fe}$ (52 to 16,700 ppm) was determined for cleat-filling calcites in the Herrin, Springfield, and Colchester Coals, using focussed synchrotron radiation. Compositional zonation in the calcites reflects a multistage history of precipitation from fluids with differing trace-element characteristics. In nearly all of the samples, a high $\mathrm{Fe}(\geq \sim 5000 \mathrm{ppm})$ calcite is the latest composition to form, replacing earlier stages with varying, but generally lower Fe contents. Partitioning data for Sr suggest that a typical calcite with $200 \mathrm{ppm} \mathrm{Sr}$ formed from a fluid with a Sr/Ca of about 0.005 . This $\mathrm{Sr} / \mathrm{Ca}$ is $\sim 4$ times lower than seawater, and $\sim 12$ times lower than the average for present day Illinois Basin saline formation waters. Formation of cleat-filling calcite is best explained by precipitation from fluids similar to present day dilute (shallow) formation waters having a meteoric source.
\end{abstract}

\section{Introduction}

Bituminous coals were produced in the Illinois basin as Pennsylvanian organic material was buried to a minimum depth of about $1500 \mathrm{~m}$ (Damberger 1971). During its formation, very small scale $\mid<1$ to several $\mathrm{m}$ wide) subvertical fractures, known as cleats, developed in the coal, the result of dehydration, devolitilization, and stress (Ting 1977). After basin sedimentation ceased, overlying sediments were gradually eroded to the present level, where Pennsylvanian coals occur from the surface to a depth of about $370 \mathrm{~m}$.

At all stages of basin history, fluids have migrated through the coal seams, resulting in mineralization along the cleats. Early on, the fluid was saline, similar to present day formation waters at depth in the Illinois basin. At the present level of erosion, the original basinal brine has been replaced by less saline meteoric formation waters, derived from surface water or rainwater. The sequence of cleat mineralization is consequently an

\footnotetext{
${ }^{1}$ Manuscript received March 3, 1992; accepted June 15, 1993.

${ }^{2}$ Present Address: Department of Geology, University of Nebraska, Lincoln, NE 68588.

${ }^{3}$ Illinois State Geological Survey, 615 East Peabody Drive, Champaign, IL 61820.
}

important indicator of diagenetic fluid movement during the evolution of coal-forming sedimentary basins.

In this study, we consider calcite-forming fluids present during the last of three stages of cleatfilling mineralization in Illinois basin coals. Sr, $\mathrm{Mn}$, and $\mathrm{Fe}$ microdistributions have been determined for 15 cleat-filling calcite samples, using focussed synchrotron radiation. Trace-element and petrographic data are used to examine the growth history of the cleat-filling calcite, and to assess the trace-element characteristics and source(s) of the calcite-forming fluids.

\section{Previous Work}

Studies by Cobb (1981) and Whelan et al. (1988) have established the relative timing of cleat mineralization in Illinois basin coals. Prior to the calciteforming stage, an initial stage of kaolinite + quartz mineralization took place. This was followed by a sulfide stage that includes at least two generations of cleat pyrite. In the northern part of the basin, the sulfide stage is represented by sphalerite, deposited by deep-basin hydrothermal brines (Hatch et al. 1976; Cobb 1981; Whelan et al. 1988). 
Oxygen isotopic studies of whole-cleat calcite separates (Shieh and Suter 1979; Anderson et al. 1980; Whelan et al. 1988) show $\delta^{18} \mathrm{O}$ values ranging from 21 to 26 per mil (relative to SMOW), and infer a meteoric source for its fluid. Shieh and Suter (1979) assumed that the calcite formed from present day coal mine seepage water having a $\delta^{18} \mathrm{O}$ of -6.3 per mil, and calculated calcite formation temperatures of $13^{\circ} \mathrm{C}-28^{\circ} \mathrm{C}$, using the fractionation curves of $\mathrm{O}^{\prime} \mathrm{Neil}$ et al. (1969). Whelan et al. (1988) calculated a minimum calcite formation temperature of about $15^{\circ} \mathrm{C}$, assuming that Illinois Basin meteoric water with a $\delta^{18} \mathrm{O}$ of -6 per mil (Clayton et al. 1966) was the most ${ }^{18} \mathrm{O}$-depleted water that could have formed the calcite. An upper temperature limit of about $70^{\circ} \mathrm{C}$ was suggested by Whelan et al. (1988), based on the absence of a vapor phase in cleat calcite fluid inclusions. Because of the uncertainty in temperature of formation and/or $\delta^{18} \mathrm{O}$ of the corresponding water, formation of the calcite from deep basin saline waters cannot be ruled out from oxygen isotope data alone. A meteoric source is however suggested by $\delta \mathrm{D}$ values $(-58$ and -80 per mil, relative to $\mathrm{PDB})$ of inclusion fluids in two calcite samples analyzed by Whelan et al. (1988; see their figure 6).

\section{Methods}

Cleat-filling calcite samples from the Herrin (No. 6), Springfield (No. 5), and Colchester (No. 2) Coals were collected from active mines in the Illinois basin (figure 1). The sequence of calcite precipitation was determined for each sample by petrography under cathodoluminescence. $\mathrm{Sr}, \mathrm{Mn}$, and $\mathrm{Fe}$ concentrations were determined using the X-ray fluorescence microprobe at the National Synchrotron Light Source, Brookhaven National Laboratory. Compared to electron microprobe analyses, this technique offers better detection limits by an order of magnitude, with comparable spatial resolution (Sutton et al. 1988; Jones and Gordon 1989; Lu et al. 1989). In this method, samples are placed in highly collimated synchrotron radiation, and Xray fluorescence spectra are obtained using a $\mathrm{Si}(\mathrm{Li})$ energy-dispersive detector. $\mathrm{Sr}, \mathrm{Mn}$ and Fe concentrations were obtained by comparing the yields for these elements to that of $\mathrm{Ca}$ in calcite, which was assumed to be stoichiometric $(\mathrm{Mg}$ content of calcite separates is $\leq 1600 \mathrm{ppm}$; Chou, unpub. data, 1990). Precision of this method is within $\pm 15 \%$ of the amount present (Lu et al. 1989), with detection limits of about $5 \mathrm{ppm}$ for the elements of interest in calcite (Kopp et al. 1990; Budd et al. 1993). Spatial resolution of $\leq 10 \mu \mathrm{m}$ is routinely achieved.

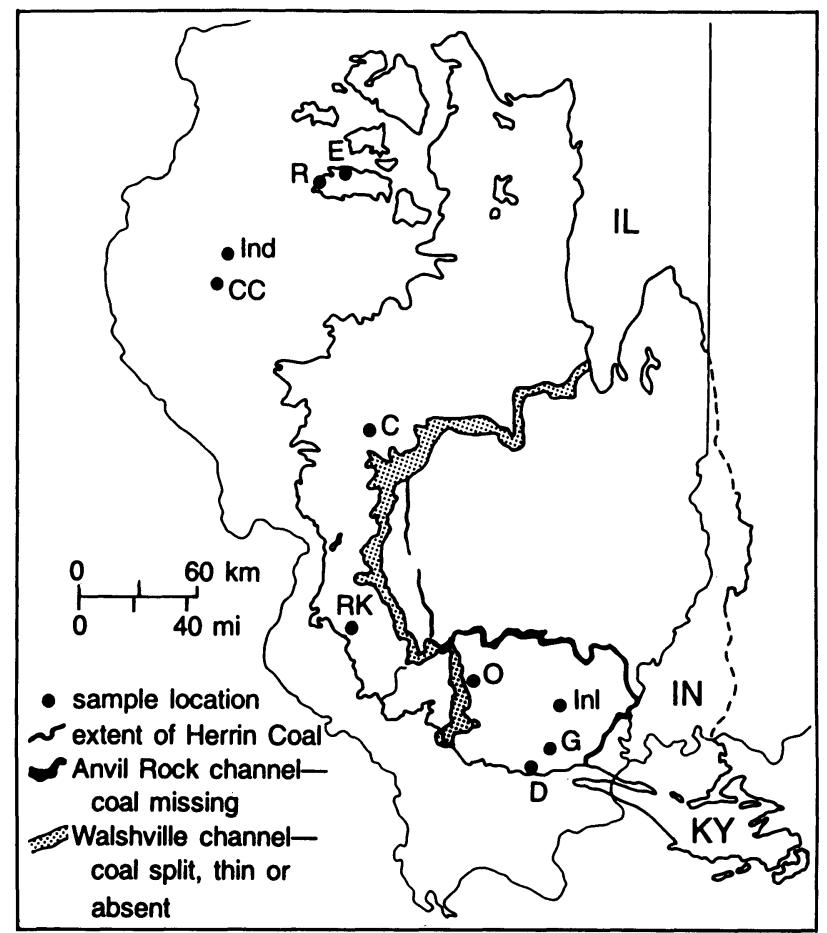

Figure 1. Locations of $10 \mathrm{coal}$ mines from which cleat calcite samples were collected. Names of mines are abbreviated as following: C, Crown II; CC, Cedar Creek; D, Delta; E, Elm; G, Galatia; Inl, Inland No. 2; Ind, Industry; O, Orient No. 6; R, Rapatee; and RK, River King UG No. 1 mine. Also indicated are the extent of the Herrin Coal and the Walshville channel which is contemporaneous with the Herrin Coal. The extent of the Springfield Coal, not shown in the figure, is close to that of the Herrin Coal. The Colchester Coal is mined at the Cedar Creek and Industry mines. The Colchester Coal area extends beyond that of the Herrin and Springfield Coals (Treworgy and Bargh, 1984).

Compositional variation over a scale of several millimeters can be shown by two-dimensional step scans.

\section{Results}

In all but one of the calcites examined, differences in luminescent intensity show a sequence of precipitation, dissolution, and reprecipitation, in stages having distinct trace-element compositions. High Fe ( $\geq \sim 5000 \mathrm{ppm}$; very dull luminescent) calcite is typically the last phase to form, replacing one or more earlier stages of low-Fe (moderate luminescent) or moderate-Fe (dull luminescent) calcite (figures 2 and 3). Depending on the sample, this sequence may be shown by zoned crystals with multistage overgrowths, or by multigenerations with crosscutting crystal boundaries (figures 2 and 3 ). As many as five distinct calcite 


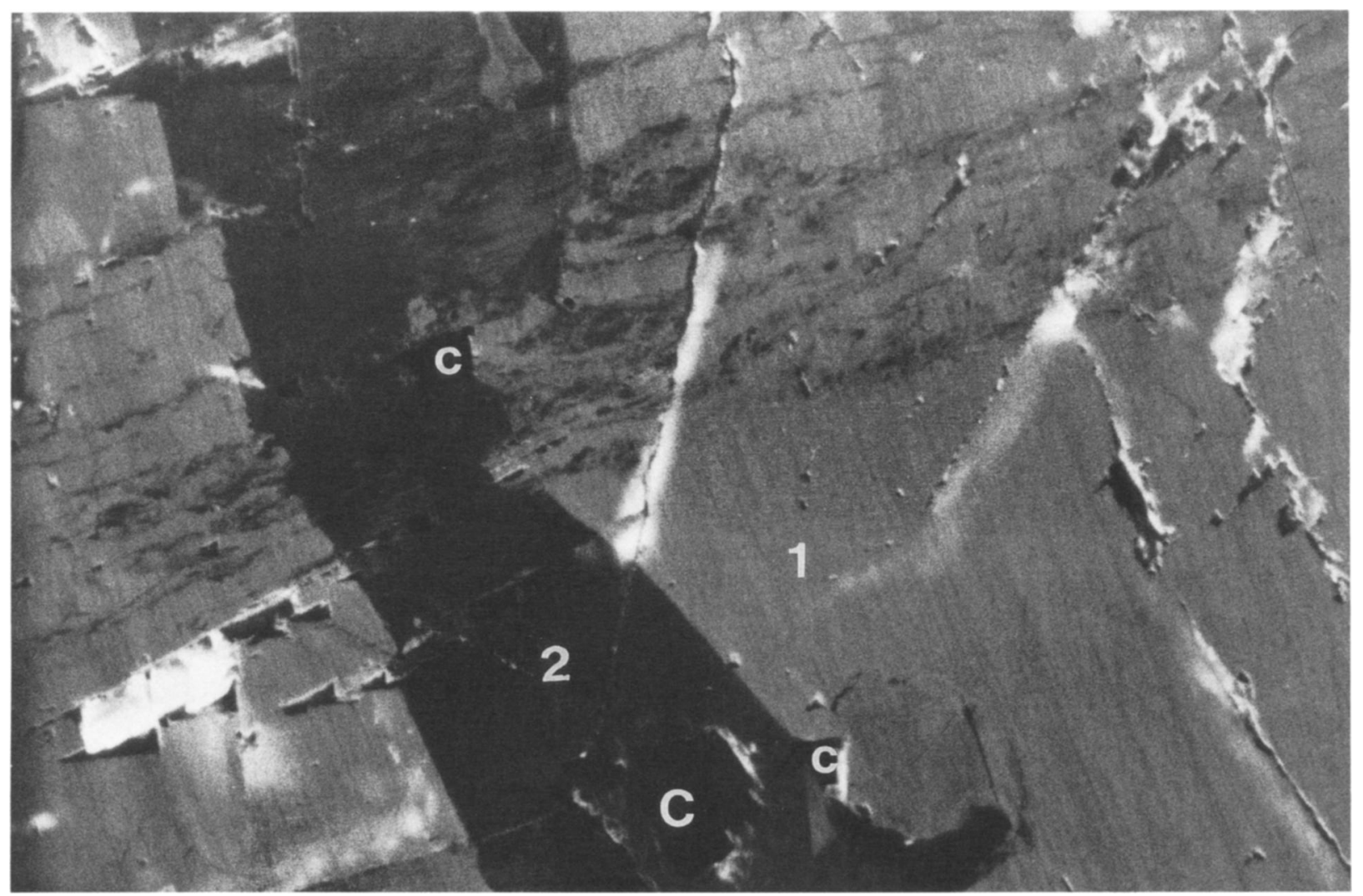

Figure 2. Photomicrograph of sample CLC-47 taken under cathodoluminescence, showing early, low-Fe calcite (moderate luminescent; zone (1), and later, high-Fe calcite (very dull luminescent; zone (2) containing fragments of coal (non-luminescent; indicated by C). Width of the field of view equals $1.25 \mathrm{~mm}$.

stages were observed, consistent with field observations showing up to five calcite veinlets in a single cleat (Hatch et al. 1976). In several samples, the high-Fe calcite is concentrated along fractures and contains coal fragments, possibly carried in from the cleat walls by the latest fluids (figure 2). Coal fragments appear to be absent from earlier calcite stages.

No systematic compositional differences were found between calcites in each of the major Illinois basin coal beds, nor among calcites from different depths or geographic locations. Manganese concentration varies from $786 \mathrm{ppm}$ to $9480 \mathrm{ppm}$, iron from $52 \mathrm{ppm}$ to $16,700 \mathrm{ppm}$, strontium from below detection limit to $461 \mathrm{ppm}$ (figure 4). The Fe concentrations show a general positive correlation with Mn contents, but Fe variation is greater, resulting in $\mathrm{Fe} / \mathrm{Mn}$ ratios that vary from $<0.02$ in the lowest $\mathrm{Fe}$ zones to $>3.0$ in some high-Fe calcites (figure 4). The availability of both $\mathrm{Fe}$ and $\mathrm{Mn}$ are strongly tied to redox equilibria, and the observed variations may simply reflect changes in redox conditions of the calcite-forming fluids (Morse and Mackenzie 1990). Strontium concen- trations of the calcites average about $200 \mathrm{ppm}$ and do not show a consistent variation with increasing $\mathrm{Fe}$ and $\mathrm{Mn}$. The data suggest that between stages of calcite formation, the $\mathrm{Sr} / \mathrm{Ca}$ ratio of the calciteforming fluid remained fairly constant, while $\mathrm{Fe}$, $\mathrm{Mn}$ and $\mathrm{Fe} / \mathrm{Mn}$ changed dramatically, producing large changes in luminescent intensity (Hemming et al. 1989|.

\section{Sources of the Calcite-Forming Fluids}

To evaluate the origin of the cleat-filling calcites, present day Illinois basin formation waters are considered as possible calcite-forming fluids. We rely primarily on the $\mathrm{Sr} / \mathrm{Ca}$ ratio because these divalent ions are not strongly affected by changes in redox conditions, and because $\mathrm{Mn}$ and Fe concentrations are known to be more highly variable in Illinois Basin waters (Steuber and Walter 1991; Steuber et al. 1993). The Sr/Ca ratio of average saline formation water in the Illinois Basin is about 0.06 , or roughly three times greater than seawater (table 1). The Sr/Ca ratio of Illinois Basin waters is strongly influenced by carbonate diagenesis, increasing as 


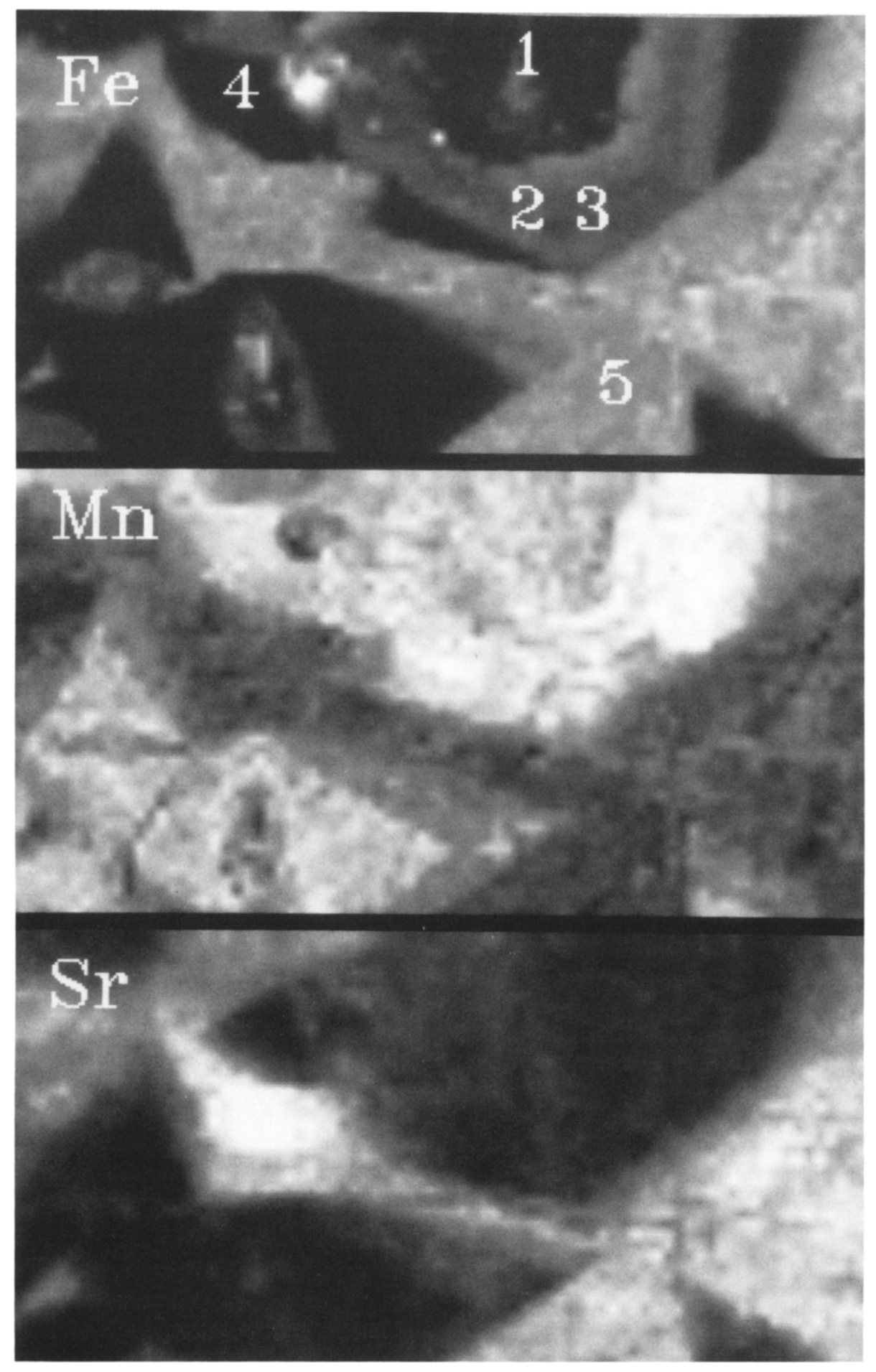

Figure 3. 2-D scan showing distribution of Fe (top of figure), $\mathrm{Mn}$ (center), and $\mathrm{Sr}$ (bottom) among five distinct calcite compositions observed in sample CLC-210. Images show an early stage of low-Fe calcite (zone 1), followed by successive stages of low- to moderate-Fe calcite (zones 2 and 3); very low-Fe calcite (zone 4); and finally, a zone of high-Fe calcite (zone 5). This sample does not follow the general correlation of Fe and $\mathrm{Mn}$, as $\mathrm{Mn}$ is highest in zones 2 and 3 rather than in high-Fe zone 5 . Area scanned is $1 \times 2 \mathrm{~mm}$, and pixel size is $25 \mu \mathrm{m}$ square. 


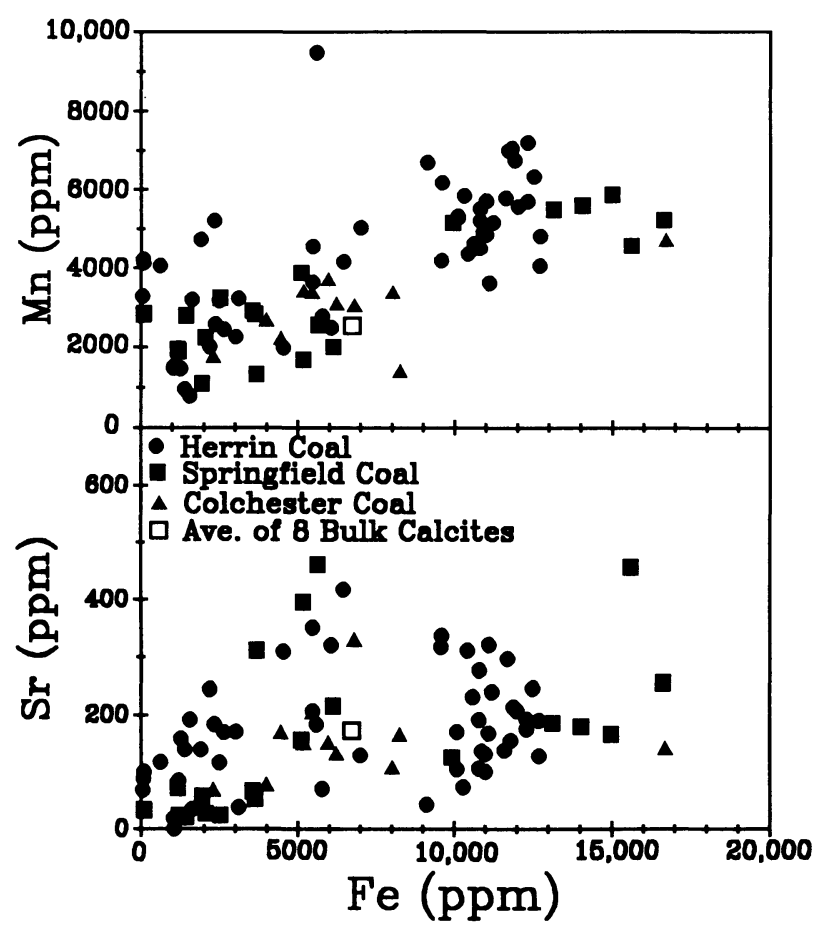

Figure 4. Plot of $\mathrm{Sr}$ and $\mathrm{Mn}$ versus Fe for cleat calcites in Herrin Coal (solid circles), Springfield Coal (solid squares), and Colchester Coal (solid triangles). Each point represents a single synchrotron spot analysis. Open square is the average of 8 bulk samples of cleat-filling calcite, analyzed by atomic absorption (Chou, unpub. data, 1990).

$\mathrm{Ca}$ is taken into re-precipitated calcite, while $\mathrm{Sr}$, with a calcite/fluid $K_{D}$ that is much less than one, remains in the fluid (Morse and Mackenzie 1990; Steuber and Walter 1991; Steuber et al. 1993). In order to form a cleat-filling calcite with $200 \mathrm{ppm}$ $\mathrm{Sr}$ from saline formation water having a $\mathrm{Sr} / \mathrm{Ca}$ of 0.06 , a $K_{D}$ of 0.008 is required. Even if all possible sources of $K_{D}$ variations in calcite are considered le.g., temperature, biogenic fractionation, precipi- tation rate, crystallographic variation), this value is an order of magnitude below the range of published $K_{D}$ s (about 0.05 to 0.30 ) and suggests that the cleat-filling calcites did not form from deep basin saline waters.

Shieh and Suter (1979) suggested that Illinois Basin cleat-filling calcites formed from present day meteoric groundwater that percolated through the coal. Compared to seawater or Illinois Basin brines, average meteoric surface water has a much lower $\mathrm{Sr} / \mathrm{Ca}$ ratio ( 0.004; Martin and Meybeck 1979), requiring a calcite/fluid $K_{D}$ of 0.13 for calcite with $200 \mathrm{ppm}$ Sr. If cleat-filling calcite formed from meteoric groundwater, $K_{D}$ data suggest that the $\mathrm{Sr} /$ $\mathrm{Ca}$ ratio of the fluid was not greatly affected by interaction with the coal, possibly indicating a relatively open system. Analyses of calcite-saturated meteoric groundwater emanating from coals in Illinois Basin coal mines are given by Gluskoter (1965). Although Sr concentrations were not determined, $\mathrm{Fe} / \mathrm{Ca}(0.005)$ and $\mathrm{Mn} / \mathrm{Ca}(0.001)$ of average mine waters provide a good match for the high-Fe latest calcite, requiring $K_{D}$ values of 5.0 and 12.5 , respectively, for a typical calcite with $10,000 \mathrm{ppm}$ Fe and 5000 ppm Mn (table 1).

\section{Conclusions}

Cleat mineralization provides a valuable record of diagenetic fluid movement in coal-forming sedimentary basins. Synchrotron-probe data show repeated changes in the trace-element composition of fluids present during the latest diagenetic stage in Illinois Basin coals. Our data do not support a deep-basin source for the calcite-forming fluid. Taken together with existing stable isotope data and the position of the calcites at the end of the cleat-filling sequence, trace-element data are more consistent with calcite formation from fluids simi-

Table 1. Compilation of Mean Compositions for Illinois Basin Formation Waters

\begin{tabular}{lccc}
\hline & $\begin{array}{c}\text { Silurian-Devonian Waters } \\
\text { (Steuber and Walter 1991) }\end{array}$ & $\begin{array}{c}\text { Mississippian-Pennsylvanian } \\
\text { (Steuber et al. 1993) }\end{array}$ & $\begin{array}{c}\text { Coal Mine Waters } \\
\text { (Gluskoter 1965) }\end{array}$ \\
\hline Number of Samples & 51 & 74 & 26 \\
Depth Range (m) & $184-1622$ & $128-1017$ & $37-242$ \\
Salinity (g/l) & $97.5 \pm 43.1$ & $112.8 \pm 32.5$ & $21.4 \pm 18.2$ \\
& Mean Concentrations for Selected Elements (ppm) & \\
$\mathrm{Ca}$ & $4501 \pm 2489$ & $4098 \pm 1686$ & $309 \pm 332$ \\
$\mathrm{Fe}$ & $3.4 \pm 8.2$ & $10.5 \pm 22.8$ & $1.7 \pm 2.5$ \\
$\mathrm{Mn}$ & $.51 \pm .52$ & $.83 \pm .98$ & $.33 \pm .32$ \\
$\mathrm{Sr}$ & $257 \pm 159$ & $239 \pm 154$ &.. \\
$\mathrm{Sr} / \mathrm{Ca}^{\mathrm{b}}$ & .057 & .058 & $\cdots$ \\
\end{tabular}

${ }^{a}$ Mississippian-Pennsylvanian averages exclude sample 196 for which $\mathrm{Mn}=38.7$ and $\mathrm{Fe}=2850 \mathrm{ppm}$.

${ }^{b} \mathrm{Sr} / \mathrm{Ca}$ determined from average concentrations reported above. 
lar to present-day shallow formation waters having a meteoric source. Our results support previous interpretations of stable isotope data for calcite separates, but reveal a more complex history of calcite precipitation.

\section{ACKNOWLEDGMENTS}

We are grateful to Keith W. Jones of Brookhaven National Laboratory, and J. V. Smith of the University of Chicago, for their support during A. Kolker's postdoctoral research associateship at BNL. We thank Bruce Ward for assistance with cathodoluminescent petrography, Olden Draughn for preparing polished thin sections, and Alan Stueber for providing data on Illinois basin formation waters.
Steve Sutton and Mark Rivers offered their insights into operation of the X-ray microprobe and subsequent processing of spectra and images. Discussions with Gil Hanson, Bill Meyers, Jeanne Pacquette, Martin Schoonen, and John Suen have also been beneficial. Heinz Damberger and Richard Harvey provided initial reviews of the manuscript, followed by the reviews of 4 Journal of Geology reviewers. This study was supported by U.S. Department of Energy contract No. DE-AC0276CH00016. Support for NSLS beamline X-26A was provided by NSF Grants EAR 86-13862 (to J. V. Smith) and EAR 89-15699 (to Mark Rivers). Additional support for X-26A was provided by a State of Illinois Technology Challenge Grant to the Consortium for Advanced Radiation Sources.

\section{REFERENCES CITED}

Anderson, T. F., Brownlee, M. E., and Phillips, T. L., 1980, A stable isotope study on the origin of permineralized peat zones in the Herrin Coal: Jour. Geology, v. 88, p. $713-722$.

Budd, D. A., Hammes, U., and Vacher, H. L., 1993, Calcite cementation in the upper Floridan aquifer: a modern example for confined-aquifer cementation models?: Geology, v. 21, p. 33-36.

Clayton, R. N.; Friedman, I.; Graf, D. L.; Mayeda, T. K.; Meents, W. F.; and Shimp, N. F., 1966, The origin of saline formation waters, 1. Isotopic composition: Jour. Geophys. Res., v. 71, p. 3869-3882.

Cobb, J. C., 1981, Geology and geochemistry of sphalerite in coal: Unpub. Ph.D. dissertation, University of Illinois, $204 \mathrm{p}$.

Damberger, H. H., 1971, Coalification pattern of the Illinois Basin: Econ. Geol., v. 66, p. 488-494.

Gluskoter, H. J., 1965, Composition of ground water associated with coal in Illinois and Indiana: Econ. Geol., v. 60, p. $614-620$.

Hatch, J. R.; Gluskoter, H. J.; and Lindahl, P. C., 1976, Sphalerite in coals from the Illinois Basin: Econ. Geol., v. 71, 613-624.

Hemming, N. G.; Meyers, W. J.; and Grams, J. C., 1989, Cathodoluminescence in diagenetic calcites: the roles of $\mathrm{Fe}$ and $\mathrm{Mn}$ as deduced from electron probe and spectrophotometric measurements: Jour. Sed. Petrology, v. 59, p. 404-411.

Jones, K. W., and Gordon, B. M., 1989, Trace element determinations with synchrotron-induced X-ray emission: Anal. Chem., v. 61, p. 341A-358A.

Kopp, O. C.; Reeves, D. K.; Rivers, M. L.; and Smith, J. V., 1990, Synchrotron X-ray fluorescence analysis of zoned carbonate gangue in Mississippi Valley-type deposits: Chem. Geol., v. 81, p. 337-347.

Lu, F.-Q.; Smith, J. V.; Sutton, S. R.; Rivers, M. L.; and Davis, A. M., 1989, Synchrotron X-ray fluorescence analysis of rock-forming minerals: Chem. Geol., v. 75 , p. $123-143$.
Martin, J.-M., and Meybeck, M., 1979, Elemental massbalance of material carried by major world rivers: Marine Chem., v. 7, p. 173-206.

Morse, J. W., and Mackenzie, F. T., 1990, Geochemistry of Sedimentary Carbonates: New York, Elsevier, 707 p.

O'Neil, J. R.; Clayton, R. N.; and Mayeda, T. K., 1969, Oxygen isotope fractionation in divalent metal carbonates: Jour. Chem. Phys. v. 51, p. 5547-5558.

Shieh, Y.-N., and Suter, T. G., 1979, Formation conditions of authigenic kaolinite and calcite in coals by stable isotope determinations: Clays and Clay Minerals, v. 27, p. 154-156.

Steuber, A. N., and Walter, L. M., 1991, Origin and chemical evolution of formation waters from Silurian-Devonian strata in the Illinois basin, USA: Geochim. Cosmochim. Acta, v. 55, p. 309-325.

_- - - Huston, T. J.; and Pushkar, P., 1993, Formation waters from Mississippian-Pennsylvanian reservoirs, Illinois basin, USA: chemical and isotopic constraints on evolution and migration: Geochim. Cosmochim. Acta, v. 57, p. 763-784.

Sutton, S. R.; Rivers, M. L.; Smith, J. V.; Brown, G. E., Jr.; and Jones, K. W., 1988, Synchrotron X-ray sources in the earth sciences EOS (Trans. Am. Geophys. Union), v. 69, p. 1666-1667.

Ting, F. T. C., 1977, Origin and spacing of cleats in coal beds: Jour. Pressure Vessel Tech., v. 99, p. 624-626.

Treworgy, J. D., and Bargh, M. H., 1984, Coal Resources of Illinois maps: Herrin (No. 6) Coal, 1 sheet; Springfield (No. 5) Coal, 1 sheet; Colchester (No. 2), Dekoven, and Jamestown Coals, 1 sheet; Illinois State Geol. Survey, scale 1:500,000.

Whelan, J. F.; Cobb, J. C.; and Rye, R. O., 1988, Stable isotope geochemistry of sphalerite and other mineral matter in coal beds of the Illinois and Forest City basins: Econ. Geol., v. 83, p. 990-1007. 